\title{
Manned spaceflight planned
}

\section{Tokyo}

JAPAN's ambition to put men in space is at last beginning to win serious backing. For the first time ever, the Space Activities Commission, the nation's space policymaking body, last week approved a policy plan for the next ten years that calls for study of manned space flight. But of more immediate significance are decisions by the commission to allow the Institute of Space and Astronautical Science (ISAS) to build bigger solid-fuel rockets for interplanetary scientific missions and to let the National Space Development Agency (NASDA) develop an unmanned cargo shuttle.

Confirmation of earlier reports (see Nature 339, 245; 25 May 1989) that ISAS is now free from political constraints on the size of its rockets and can aim at scientific missions to the Moon and planets was well received. Minoru Oda, former director general of ISAS and a key mover behind the policy change, is "very pleased" that the "artificial restraint" on rocket size has at last been removed and sees it as a "really big breakthrough".

Officials at NASDA, which is affiliated with the Science and Technology Agency (STA), are also pleased that the new space policy calls for development of an unmanned space shuttle which will be carried into space on top of NASDA's H-2 rocket. The shuttle, called HOPE $(\mathrm{H}-2$ orbiting plane), will be used to transport cargo to the Japanese module on the US space station and is expected to cost about $¥ 300,000$ million, $(\$ 2,000$ million). The US space station is central to the ten-year space policy.

After a prolonged delay caused by Japan's Recruit scandal, the Diet recently approved the US-Japan intergovernmental agreement on the station, thereby allowing NASDA to go ahead with construction of Japan's $\$ 2,000$-million module for the station. And as the costs of Japan's space activities rise in the $1990 \mathrm{~s}$, the commission hope that Japan's private sector will make significant investments in space.

Apart from the station, the new policy calls for increased international collaboration, for example to monitor global environmental problems such as ozone depletion and the greenhouse effect. And Tateo Arimoto of NASDA's international affairs division is confident that, as a result of the new policy, STA will be able to win funds to begin construction of a large polar-orbiting Earth observation satellite in fiscal year 1990.

The Advanced Earth Observing Satellite (ADEOS), tentatively scheduled to be launched by an H-2 rocket in 1994, will carry sensors developed by NASDA, the US National Aeronautics and Space
Administration, the European Space Agency, and possibly several other countries, and will monitor such things as the ozone layer, wind speed at the Earth's surface and reflectivity of the oceans and land (see Nature 335, 486; 1988).

But the new space policy does open up the possibility of conflict between ISAS and NASDA. Until now, the roles of the two space agencies have been clearly defined. ISAS carries out small-scale scientific missions while NASDA

\section{RAIN FORESTS \\ Germans aid Brazil}

Munich \& Sao Paolo

IN keeping with its newly discovered concern about rain-forest destruction, Brazil has accepted DM100 million (about \$50 million) of grants and low-interest loans from West Germany for the protection of its tropical rain forests. The money will be invested by 1990 to build up the Brazilian Institute of the Environment and Natural Renewable Resources (IBAMA in Portuguese) and to help establish and maintain forest preserves. An additional DM50 million will be given or lent for other environmental projects unrelated to forest preservation.

Money will be spent to support "longterm, ecologically defensible development of the rain forests", a goal that fits in with the current Brazilian trend toward conciliating economic development and the environment. Some of the money will also go to protect the Atlantic coastal forests, which have been reduced to 5 per cent of the area they covered when the Portuguese arrived in the year 1500 .

Until early this year, Brazil rejected attempts by developed nations to preserve rain forests. Brazilian leaders dismissed European and North American donors as "environmental imperialists" seeking to meddle in its internal affairs.

The money is expected to be spent on existing projects as well as new projects. West Germany is not giving Brazil a blank cheque; rather, a joint commission has to agree on all proposals.

That West Germany was willing to give the aid came as no surprise; trying to save the rain forests has become one of the most popular environmental causes of the day. In 1988, West Germany announced a special programme of DM250 million in aid for tropical rain forests. The wellpublicized hearings of a parliamentary committee on "protecting the Earth's atmosphere" created a "fertile political soil" for giving aid, said Rolf Lerche of the Economic Development Ministry.

Steven Dickman \& Ricardo Bonalume Neto launches large application satellites. But NASDA officials make no secret of the fact that they, like ISAS, would like to begin missions to the Moon and planets using the soon-to-be-completed $\mathrm{H}-2$ rocket.

Oda says that the $\mathrm{H}-2$ rocket may in future be used for "large-scale" interplanetary or lunar missions. But he hopes that over the next $10-15$ years, Japanese scientists will be clever enough to use the "modest" launch capabilities of ISAS rockets. Alternatively, for large-scale missions, total international collaboration may be the best way to go, he says.

David Swinbanks

\section{INDIAN EDUCATION Gandhi warned}

\section{New DelhI}

SCIENCE and technology education in India is in a state of crisis, according to Prime Minister Rajiv Gandhi's science advisory council. To improve the quality of education, the council has proposed a $\$ 1,000$ million action programme for Gandhi to implement during the eighth five-year plan (1990-95).

There are shortages of manpower in most areas of advanced science and technology, especially in the physical sciences and mathematics, says the council, and there are no institutions in the country that provide even moderately acceptable science education at the undergraduate level. In even the best kinds of institutions, such as the Indian Institutes of Technology and the Indian Institute of Science at Bangalore, facilities are totally inadequate to carry out teaching and research comparable with that in advanced countries, says the council.

In most engineering colleges, the infrastructure is "very poor" and the state of the polytechnics is "deplorable". Most of the money requested would be spent on improving these. The council also recommends the establishment of at least two centrally sponsored but autonomous "model" colleges in each state for undergraduate science students.

After graduating from these colleges, students would take a five-year postgraduate course in selected universities, working closely with the country's leading research institutes. India's national laboratories (of which there are more than 100 ) could provide postgraduate courses in engineering and technology. The council's chairman, Professor C. N. R. Rao, says this is the only way the country can train the necessary manpower.

The council also suggests the creation of more inter-university centres of excellence, similar to those recently set up for the nuclear sciences and astrophysics. And it proposes the creation of four regional libraries of science and technology.

K. S. Jayaraman 